\title{
MORALITAS, PENGENDALIAN INTERNAL DAN GENDER DALAM KECENDERUNGAN TERJADINYA FRAUD
}

\author{
Luh Komang Merawati dan I Nym Kusuma Adnyana Mahaputra \\ Fakultas Ekonomi, Universitas Mahasaraswati Denpasar \\ email:mettamera@gmail.com
}

\begin{abstract}
Morality, Internal Control and Gender in Fraud.University is an economic entity which is required to be accountable and transparent in funds management. Accountability can be indicated through financial reporting that is free from fraud. Fraud refers to the intentionally accounting errors to mislead the financial statement readers and usersin order to taking advantages. This research conducted with research design experiments $2 \times 2$ factorial by adding a gender perspective in examining the tendency of commit accounting fraud between individuals who have a (high or low) level of moral reasoning and (with or without) elements of internal control organization as factors that could cause accounting fraud. Data was analyze with two-ways ANOVA and Mann Whitney test in testing hypotheses. Research results indicate significant differences in the tendency of the accounting fraud due to the level of morality, internal control and gender. The results of this study are expected to provide recommendations in evaluating internal control policy to prevent fraudulent accounting practices and the importance of ethics and character education in the university environment to reduce the intention of fraud.
\end{abstract}

Keywords: fraud, gender, morality, internal control

Abstrak: Moralitas, Pengendalian Internal dan Gender Dalam Kecenderungan Terjadinya Fraud.Perguruan Tinggi merupakan entitas ekonomi yang juga dituntut untuk selalu akuntabel dan transparan dalam pengelolaan dana. Akuntabilitas dapat ditunjukkan melalui pelaporan keuangan yang bebas dari unsur fraud. Fraud adalah kecurangan akuntansi yang mengacu pada kesalahan akuntansi yang dilakukan secara sengaja untuk menyesatkan pembaca dan pengguna laporan keuangan dan bertujuan untuk mengambil keuntungan.Penelitian ini dilakukan dengan desain penelitian eksperimen $2 \times 2$ faktorial dengan menambahkan perspektif gender dalam menguji adanya kecenderungan melakukan kecurangan akuntansi antara individu yang memiliki level penalaran moral (tinggi dan rendah) dan elemen pengendalian internal organisasi (ada dan tidak ada) sebagai faktor yang akan diteliti sebagai penyebab terjadinya kecurangan akuntansi. Teknik analisis data yang digunakan adalah two ways Anova dan uji beda dalam menguji hipotesis. Hasil penelitian menunjukkan adanya perbedaan kecenderungan terjadinya kecurangan akuntansi yang disebabkan oleh level moralitas, pengendalian internal dan gender. Hasil ini diharapkan dapat memberikan rekomendasi bagi Perguruan Tinggi dalam mengevaluasi kebijakan pengendalian internal untuk mencegah terjadinya praktik kecurangan akuntansi serta pentingnya pendidikan etika dan karakter di lingkungan Perguruan Tinggi untuk mengurangi niat melakukan fraud.

Kata kunci: fraud, gender, moralitas, pengendalian internal 


\section{PENDAHULUAN}

Perguruan Tinggi merupakan entitas ekonomi yang mengelola dana yang bersumber dari perorangan, masyarakat dan ataupun pemerintah. Oleh karenanya Perguruan Tinggi juga dituntut untuk menyampaikan laporan keuangan secara berkala atas pengelolaan sumber dana tersebut kepada para stakeholder sebagai bentuk akuntabilitas keuangan. Hal ini menjadi kondisi yang tak dapat dielakkan oleh Perguruan Tinggi supaya tetap eksis, memperoleh kepercayaan masyarakat dan tetap dapat bersaing. Tuntutan transparansi dan akuntabilitas keuangan mendorong pihak manajemen untuk menghasilkan laporan berkualitas yang terbebas dari unsur fraud(Dewi dan Apandi, 2012)

Fraud atau kecurangan akuntansi mengacu pada kesalahan akuntansi yang dilakukan secara sengaja dengan tujuan menyesatkan pembaca dan pengguna laporan keuangan (Wells, 2007). Tujuan ini dilakukan dengan motivasi negatif guna mengambil keuntungan individu atau pihak-pihak tertentu. ACFE menggolongkan kecurangan akuntansi menjadi tiga jenis yaitu: penyimpangan dalam laporan keuangan (fraudulent financial reporting), penyalahgunaan aktiva (asset misappropriation) dan korupsi (corruption) (Singelton, 2010: 73).

Beberapa kasus dugaan korupsi yang marak menimpa Perguruan Tinggi di Bali diantaranya terjadi di Institut Seni Indonesia (ISI) terkait korupsi Dana Hibah B-Art sebesar 800 juta. Sementara dugaan korupsi dalam pengadaan barang dan jasa kampus diindikasikan terjadi di IHDN senilai 1,4 milyar. Universitas Udayana sebagai universitas negeri terbesar di Bali juga tak lepas dari dugaan korupsi pengadaan alat kesehatan untuk RS Khusus Pendidikan Penyakit Infeksi dan Pariwisata tahun 2009. Di ujung utara, Universitas Pendidikan Ganesha terindikasi melakukan mark up harga tanah dalam pengadaan lahan untuk kampus. Salah satu universitas swasta juga terindikasi kasus dugaan korupsi yaitu Universitas Hindu Indonesia (UNHI) yang bernaung di bawah Yayasan Pendidikan Widya Kerti milik PHDI juga dilaporkan ke pihak berwajib terkait pengelolaan dana yang tidak transparan.

Tindakan korupsi sebagai salah satu bentuk fraud yang terjadi di lingkungan Perguruan Tinggi disebabkan oleh belum efektifnya pengendalian internal di Indonesia Semakin tingginya biaya pendidikan di tingkat Perguruan tinggi menyebabkan biaya yang dikelola Perguruan Tinggi menjadi tidak sedikit. Pengawasan yang lebih ketat perlu dilakukan dalam upaya mencegah terjadinya perilaku yang mengarah pada kecurangan akuntansi. Kecurangan tersebut menyebabkan kerugian bagi stakeholder dan menciptakan masalah sosial dalam masyarakat (Dewi dan Apandi, 2012).

Fenomena terjadinya fraud ini dijelaskan oleh Bologna (1993) melalui GONE Theory yang menyatakan bahwa terdapat 4 (empat) faktor yang mendorong seseorang berperilaku menyimpang yaitu: Greed, Opportunity, Need dan Exposure. Dua faktor yakni Greed (keserakahan) dan Need (kebutuhan) berhubungan dengan faktor individual yakni perilaku yang melekat dalam individu itu sendiri sebagai pelaku kecurangan dan berkaitan dengan moralitas. Ramamoorti (2008) menyatakan bahwa faktor perilaku merupakan akar dari permasalahan mengenai fraud. Kecurangan akuntansi sangat erat hubungannya dengan etika. Salah satu teori perkembangan moral yang banyak digunakan dalam penelitian etika adalah model Kohlberg. Mengetahui level penalaran moral seseorang akan menjadi dasar untuk mengetahui kecenderungan individu melakukan suatu tindakan tertentu, terutama yang berkaitan dengan dilema etika, berdasarkan level penalaran 
moralnya. Semakin tinggi level penalaran moral individu maka akan semakin cenderung tidak berbuat kecurangan akuntansi (Wilopo ,2006).

Dua faktor lainnya yaitu opportunity (kesempatan) dan exposure (pengungkapan) merupakan faktor umum yang berhubungan dengan organisasi, seperti elemen pengendalian internal. Lima elemen pengendalian internal yang harus dimiliki oleh organisasi antara lain: lingkungan pengendalian, penetapan risiko oleh manajemen, sistem komunikasi dan informasi akuntansi, aktivitas pengendalian, dan pemantauan (Arens dan Loebecke, 2003).Organisasi yang memiliki fungsi audit internal akan lebih dapat mendeteksi kecurangan akuntansi (Coram et al., 2008), karena di dalam sistem pengendalian internal juga meliputi pengendalian akuntansi untuk menjaga kekayaan organisasi serta mengecek ketelitian dan keandalan data akuntansi (Bastian, 2006). Di sisi lain, Hogan et al. (2008) juga menemukan bahwa auditor berperan dalam mengurangi faktor kesempatan (opportunity) dalam kecurangan akuntansi. Auditor internal merupakan pihak yang bertanggungjawab dalam memeriksa efektivitas pengendalian internal (Mulyadi, 2009). Dapat disimpulkan bahwa etika dan lingkungan pengendalian akuntansi merupakan dua hal yang sangat penting terkait kecenderungan seseorang dalam melakukan kecurangan akuntansi (Hernandez dan Groot, 2007).

Penelitian ini dilakukan dengan desain penelitian eksperimen untuk membuktikan adanya kecenderungan melakukan kecurangan akuntansi antara individu yang memiliki level penalaran moral rendah dan level penalaran moral tinggi dalam kondisi terdapat elemen pengendalian internal dan tidak terdapat elemen dan pengendalian internal. Level moral individu (tinggi dan rendah) dan elemen pengendalian internal organisasi (ada dan tidak ada) merupakan faktor yang akan diteliti sebagai penyebab terjadinya kecurangan akuntansi.

Penelitian ini merupakan pengembangan dari penelitian yang telah dilakukan oleh Puspasari (2012) dan Dewi (2014) dengan menambahkan perspektif gender dalam menguji pengaruh moralitas individu dan pengendalian internal terhadap kecenderungan kecurangan akuntansi. Penelitian ini menjadi menarik dilakukan di dua PTS terbesar di Denpasar yaitu Universitas Mahasaraswati dan Universitas Warmadewa karenapenelitianpenelitian mengenai fraud sebelumnya lebih banyak dilakukan pada subyek auditor maupun pegawai di instansi pemerintahan. Penelitian tentang fraud di perguruan tinggi swasta masih sangat jarang dilakukan. Terlebih lagi kedua PTS ini sudah dikelola selama lebih dari 30 tahun, bahkan ada yang sudah mencapai umur lebih dari 50 tahun. Oleh karena itu, hasil penelitian ini diharapkan dapat memberikan rekomendasi bagi Perguruan Tinggi dalam mengevaluasi kebijakan pengendalian internal untuk mencegah terjadinya praktik kecurangan akuntansi serta pentingnya pendidikan etika dan karakter di lingkungan Perguruan Tinggi untuk mengurangi niat melakukan fraud.

\section{KAJIAN TEORI}

Kecurangan akuntansi menurut Ikatan Akuntan Indonesia (IAI) didefinisikan sebagai: (1) Salah saji yang timbul dari kecurangan dalam pelaporan keuangan yaitu salah saji atau penghilangan secara sengaja jumlah atau pengungkapan dalam laporan keuangan untuk mengelabui pemakai laporan keuangan, (2) Salah saji yang timbul dari perlakuan tidak semestinya terhadap aktiva (seringkali disebut dengan penyalahgunaan atau penggelapan) yang berkaitan dengan pencurian aktiva entitas yang berakibat laporan keuangan tidak 
disajikan sesuai dengan Prinsip Akuntansi yang Berlaku Umum (PABU).

Cressey (1953) dalam fraud triangle menjelaskan bahwa terdapat tiga faktor yang menjadi penyebab kecurangan akuntansi yaitu: rasionalisasi (rationalization), tekanan (pressure) dan kesempatan (opportunity). Faktor rasionalisasi ditunjukkan saat pelaku mencari pembenaran sebelum melakukan kejahatan, bukan sesudah melakukan tindakan tersebut, dan lebih didasari oleh kondisi psikologis pelaku (Ramamoorti, 2008), sehingga karakteristik ini tidak dapat diobservasi karena berkaitan dengan apa yang dipikirkan oleh pelaku ketika akan melakukan kecurangan akuntansi (Dorminey et al. ,2011). Oleh karena itu, tindakan kecurangan akuntansi memiliki hubungan yang sangat erat dengan perilaku etis. Albrecht (2004) menyatakan bahwa pelanggaran terhadap etika, kejujuran dan tanggung jawab merupakan inti dari tindakan kecurangan akuntansi. Permasalahan etika disebabkan oleh rasionalisasi, dan dengan beberapa perluasan, faktor tekanan (pressure) akan terkait dengan fraud dengan melihat kondisi individu yang melakukan fraud saat mempertimbangkan tindakannya benar/salah (Puspasari, 2012). Tekanan (pressure) melakukan fraud disebabkan oleh faktor ekonomi, alasan emosional, nilai (values) dan karena dorongan keserakahan.

Sementara faktor yang ketiga yaitu faktor kesempatan (opportunity) adalah kondisi atau situasi yang memungkinkan seseorang melakukan atau menutupi suatu tindakan yang tidak jujur karena kurangnya pengawasan terkait lemahnya pengawasan internal dan adanya penyalahgunaan wewenang. Faktor kesempatan ini paling memungkinkan untuk diminimalisir melalui upaya deteksi dini fraud dengan penerapan proses, prosedur, dan pengendalian internal. Yu dan Ming (2008) dan Drew dan Drew (2010) membuktikan bahwa kesesuaian sistem pengendalian internal merupakan faktor yang memengaruhi kecenderungan kecurangan akuntansi.

Semakin tinggi level penalaran moral individu akan semakin cenderung tidak berbuatkecurangan akuntansi (Wilopo, 2006) karena individu tersebut akan semakin sensitif terhadap isu-isu etika (Bernardi dan Guptill, 2008). Sementara itu individu dengan level penalaran moral yang rendah berperilaku berbeda dengan individu yang memiliki level penalaran moral yang tinggi ketika menghadapi dilema etika karena lebih cenderung akan melakukan hal-hal yang menguntungkan dirinya sendiri dan menghindari hal-hal yang dapat menimbulkan sanksi hukum. Di sisi lain, individu dengan level penalaran moral tinggi di dalam tindakannya akan memperhatikan kepentingan orang-orang di sekitarnya dan mendasarkan tindakannya pada prinsipprinsip moral karena lebih berorientasi pada prinsip-prinsip moral yang universal (Moroney dan McDevitt, 2008). Faktor kesempatan merupakan faktor penyebab kecurangan akuntansi selain faktor rasionalisasi yang berkaitan erat dengan etika. Kurangnya pengawasan dan lemahnya pengendalian internal organisasi akan menimbulkan kesempatan untuk melakukan kecurangan akuntansi. Coram et al. (2008) membuktikan bahwa organisasi yang memiliki fungsi internal audit akan lebih dapat mendeteksi kecurangan akuntansi. Hernandez dan Groot (2007) juga menemukan bahwa etika dan lingkungan pengendalian merupakan dua hal yang sangat penting terkait kecenderungan seseorang dalam melakukan kecurangan akuntansi.

Oleh karena itu hipotesis pertama dan kedua dinyatakan sebagai berikut:

H1: Terdapat perbedaan kecenderungan kecurangan akuntansi antara individu yang memiliki level moralitas tinggi dan level moralitas rendah. 
H2: Terdapat perbedaan kecenderungan kecurangan akuntansi antara individu dalam kondisi terdapat elemen pengendalian internal dan tidak terdapat elemen pengendalian internal.

Puspasari (2012) dan Dewi (2014) menemukan adanya interaksi antara moralitas individu dan pengendalian internal dalam mempengaruhi kecenderungan kecurangan akuntansi. Interaksi yang dimaksud adalah perubahan pada satu level faktor level moral atau pada kondisi pengendalian internal, akan menyebabkan perubahan individu dalam melakukan kecurangan akuntansi. Individu dengan level penalaran moral rendah cenderung akan memanfaatkan kondisi tidak terdapat elemen pengendalian internal dalam organisasi tersebut untuk kepentingan pribadinya (self-interest), misalnya tindakan yang berhubungan dengan kecurangan akuntansi. Kondisi tersebut sesuai dengan yang ada dalam tingkatan level pre-conventional Kohlberg yaitu individu yang memiliki level penalaran moral rendah memiliki motivasi utama untuk kepentingan pribadinya. Sementara itu, individu dengan level penalaran tinggi dalam kondisi tidak terdapat elemen pengendalian internal di organisasi tetap tidak akan melakukan kecurangan akuntansi yang tidak etis dan akan merugikan banyak pihak. Dengan demikian, hipotesis adanya interaksi dinyatakan sebagai berikut:

H3: Terdapat interaksi yang signifikan antara antara moralitas individu dengan pengendalian internal.

Pengujian terhadap individu yang memiliki jenis kelamin yang berbeda juga akan dilakukan pada level moralitas rendah dan tidak terdapat elemen pengendalian internal. Gender diartikan sebagai perbedaan yang tampak antara pria dan wanita dilihat dari segi nilai dan tingkah laku. Teori disonansi kognitif seringkali digunakan dalam membantu menjelaskan pengaruh gender terhadap pengambilan keputusan akuntansi, salah satunya ditunjukkan melalui sikap skeptisisme profesional auditor yang mencakup pikiran yang selalu mempertanyakan dan melakukan evaluasi secara kritis terhadap bukti audit dan tepat dalam pemberian opini. Sifat psikologis manusia yang pada dasarnya mencari kenyamanan dalam segala situasi membuat teori ini menjadi dasar mengapa wanita dan pria berbeda cara berpikir dan berperilaku serta pengolahan informasi. Noviyanti (2008) membuktikan bahwa auditor wanita menunjukkan skeptisisme profesional yang lebih tinggi dibandingkan dengan auditor pria.Chung dan Monroe (2001) menemukan bahwa auditor wanita lebih akurat dibandingkan dengan auditor pria dalam melakukan penugasan yang kompleks. Hal ini menunjukkan bahwa keberadaan wanita masih perlu diperhitungkan karena memiliki sikap konservatisme yang tinggi dan berhati-hati dalam pengambilan keputusan, cenderung menghindari risiko, serta lebih teliti (Kusumastuti dkk,2007). Oleh karena itu hipotesis empat dinyatakan sebagai berikut:

H4: Terdapat perbedaan kecenderungan kecurangan akuntansi antara individu berjenis kelamin laki-laki dengan individu berjenis kelamin perempuan pada level moralitas rendah dan tidak terdapat pengendalian internal

\section{METODE}

Penelitian ini menggunakan data primer yaitu data kuisioner yang dikumpulkan dari partisipan, dengan menggunakan teknik eksperimen lapangan dimana partisipan adalah pejabat pengelola anggaran di lingkungan Universitas Mahasaraswati Denpasar dan Universitas Warmadewa Denpasar. Prosedur eksperimen lapangan dilakukan dengan 
mendatangi setiap partisipan karena keberadaan subyek yang tidak mungkin dikumpulkan dalam satu kelas. Untuk penelitian eksperimen minimal sampel yang digunakan 15 elemen per kelompok, namun untuk penelitian eksperimen yang sederhana, dengan pengendalian yang ketat, ukuran sampel bisa antara 10-20 elemen (Sekaran,2006).

Prosedur eksperimen dimulai dengan memberikan dua buah penugasan kepada partisipan. Penugasan pertama adalah penugasan mengenai kecenderungan kecurangan akuntansi. Partisipan diberikan secara acak skenario yang menggunakan konteks orang ketiga (third-person context) yang berisi informasi mengenai peran mereka di dalam eksperimen. Terdapat dua jenis kondisi di dalam skenario kecurangan akuntansi, yaitu kondisi ada dan tidak ada elemen pengendalian internal.

Partisipan kemudian diminta mengerjakan penugasan kedua. Pada penugasan kedua, subjek akan diminta untuk membaca skenario mengenai dilema etika dan menjawab pertanyaan-pertanyaan yang akan digunakan untuk mengukur level penalaran moral mereka.Variabel independen dalam penelitian ini adalah moralitas individu (level moral tinggi dan rendah) dan pengendalian internal (ada dan tidak ada elemen pengendalian internal). Indikator moralitas individu yang digunakan dalam penelitian ini adalah berdasarkan teori perkembangan moral Kohlberg (1969). Pengukuran moralitas berasal dari model pengukuran moral yang dikembangkan oleh Kohlberg (1969) dan Rest (2000) dalam bentuk instrumen Defining Issues Test. Instrumen ini berbentuk kasus dilema etika. Moralitas diukur melalui 6 (enam) butir instrumen yang mengukur setiap tahapan moralitas melalui kasus dilema etika akuntansi. Semakin rendah hasil penjumlahan skala dari instrumen tersebut, maka tingkat moralitas individu tersebut masih berada pada tahap yang rendah yaitu level preconventional.Pengukuran variabel pengendalian internal menggunakan skenario yang dikembangkan dari penelitian Puspasari (2012) yang terdiri dari dua skema dalam skenario: ada elemen pengendalian internal dan tidak ada elemen pengendalian internal.

Variabel dependen dalam penelitian ini adalah kecenderungan kecurangan akuntansi. Association of Certified Fraud Examiners (ACFE, 2009) mengategorikan kecurangan dalam tiga kelompok yaitu: kecurangan dalam laporan keuangan, penyalahgunaan aktiva dan korupsi. Variabel ini diukur dengan skala Likert 1-10 untuk mengukur respons dari partisipan dalam memberikan pendapatnya atas pertanyaan yang mewakili ketiga jenis kecurangan akuntansi. Partisipan menjawab pertanyaan tersebut setelah membaca skenario eksperimen. Semakin tinggi partisipan memberikan angka penilaiannya, semakin cenderung partisipan tersebut berbuat curang. Skenario yang digunakan merupakan pengembangan dari skenario yang digunakan oleh Puspasari (2012) dan Dewi (2014).

Teknik analisis data yang digunakan dalam penelitian ini yaitu distribusi frekuensi untuk statistik deskriptif, uji homogenitas, dan uji normalitas data. Analisis ANOVA (two ways) dilakukan untuk menguji hubungan antara satu variabel dependen (skala metrik) dengan satu atau lebih variabel independen (skala nonmetrik atau kategorikal dengan kategori lebih dari dua). Uji beda selanjutnya digunakan untuk mengetahui apakah terdapat perbedaan kecenderungan kecurangan akuntansi yang disebabkan oleh perbedaan gender

\section{HASIL DAN PEMBAHASAN}

Penelitian ini dilakukan kepada pihak penyusun, pelaksana/pengelola anggaran yang terkait dengan pertanggungjawaban laporan keuangan di tingkat Rektorat Universitas dan 
masing-masing fakultas di dua PTS di Denpasar yakni Universitas Mahasaraswati dan Universitas Warmadewa Denpasar dengan jumlah partisipan sebanyak 100 orang. Dari 100 partisipan, empat partisipan dinyatakan gugur karena pengisian kuesioner yang tidak lengkap. Sebanyak 96 partisipan yang berhasil dilibatkan dalam penelitian ini dibagi ke dalam empat grup manipulasi.Berdasarkan tabulasi awal kuesioner diperoleh data demografi partisipan sebagai berikut.

Tabel 1. Data Demografi Partisipan

\begin{tabular}{|c|c|c|}
\hline Keterangan & Jumlah & Persentase \\
\hline Gender: & & \\
\hline a. Laki-laki & 46 & $47,9 \%$ \\
\hline b. Perempuan & 50 & $52,1 \%$ \\
\hline Usia: & & \\
\hline a. $25-50$ th & 54 & $56,3 \%$ \\
\hline b. $>50$ th & 42 & $43,7 \%$ \\
\hline Lama Bekerja: & & \\
\hline a. $<5$ th & 3 & $3,2 \%$ \\
\hline b. $5-10$ th & 5 & $5,2 \%$ \\
\hline c. $>10$ th & 88 & $91,6 \%$ \\
\hline \multicolumn{3}{|l|}{ Pendidikan terakhir: } \\
\hline a. $\mathrm{S} 1$ & 12 & $12,5 \%$ \\
\hline b. $S 2$ & 56 & $58,3 \%$ \\
\hline c. S3 & 28 & $29,2 \%$ \\
\hline
\end{tabular}

Hasil analisis statistik deskriptif menunjukkan nilai mean dan standar deviasi masingmasing grup ditunjukkan dalam tabel 2 berikut ini. Grup 4 dalam kondisi moral rendah dan tidak ada pengendalian internal menunjukkan nilai mean paling tinggi sebesar 8,227.

Tabel 2. Statistik Deskriptif

\begin{tabular}{llccc}
\hline Moral & SPI & Mean & Std. Deviation & N \\
\hline Rendah & Ada SPI (Grup 3) & 5,125 & 3,111 & 24 \\
& Tidak ada SPI (Grup 4) & 8,227 & 2,308 & 22 \\
& Total & 6,676 & 2,709 & 46 \\
Tinggi & Ada SPI (Grup 1) & 4,769 & 3,102 & 26 \\
& Tidak ada SPI (Grup 2) & 4,125 & 2,525 & 24 \\
& Total & 4,447 & 2,813 & 50 \\
Total & Ada SPI & 4,947 & 6,213 & 50 \\
& Tidak ada SPI & 6,176 & 2,417 & 46 \\
& Total & 5,562 & 4,315 & 96 \\
\hline
\end{tabular}

Pengujian instrumen dilakukan untuk mengetahui validitas dan reliabilitas. Hasil uji validitas dan reliabilitas pada Tabel 3 menunjukkan bahwa masing-masing instrumen memiliki nilai pearson correlation $>0,30$ dan nilai cronbach alpha $>0,70$. Hal ini berarti indikator/ pertanyaan dalam kuesioner dapat dinyatakan valid dan reliabel.

Salah satu asumsi analysis of variance (ANOVA) yang harus dipenuhi adalah melalui uji normalitas. Hasil pengujian normalitas ditunjukkan pada Tabel 4dengan 
Kolmogorov-Smirnov Test menunjukkan nilai Asymp. Sig 0,066>0,05, oleh karena itu dapat disimpulkan bahwa data terdistribusi dengan normal.

Tabel 3. Hasil Uji Validitas dan Reliabilitas

\begin{tabular}{|c|c|c|}
\hline Variabel & $\begin{array}{l}\text { Pearson } \\
\text { Correlation }\end{array}$ & Keterangan \\
\hline \multicolumn{3}{|l|}{ Moralitas Individu } \\
\hline MI.1 & 0,773 & \\
\hline MI.2 & 0,883 & \\
\hline MI.3 & 0,670 & \\
\hline MI.4 & 0,576 & \\
\hline MI.5 & 0,649 & \\
\hline MI.6 & & \\
\hline \multicolumn{3}{|c|}{ Cronbach Alpha } \\
\hline Moralitas Individu & 0,793 & Reliabel \\
\hline
\end{tabular}

Tabel 4. Hasil Uji Normalitas

One-Sample Kolmogorov-Smirnow Test

\begin{tabular}{|ll|r|}
\hline & & $\begin{array}{r}\text { Unstandardiz } \\
\text { ed Residual }\end{array}$ \\
\hline Normal Parameters & & 96 \\
& Mean & .0000000 \\
Most Extreme Differences & Std. Deviation & 2.91214031 \\
& Absolute & .133 \\
& Positive & .112 \\
Kolmogorov-Smirnov $Z$ & Negative & -.133 \\
Asymp. Sig. (2-tailed) & & 1.305 \\
\hline
\end{tabular}

a. Test distribution is Normal.

Untuk selanjutnya uji homogenitas melalui Levene's Test pada Tabel 5dilakukan untuk mengetahui apakah keempat perlakuan(perlakuan 1,2,3, dan 4) mempunyai varian yang sama. Hasil uji statistik menunjukkan nilai sig. sebesar $0,153>0,05$. Hal ini menunjukkan bahwa setiap kelompok subjek telah memenuhi asumsi ANOVA karena memenuhi varian yang sama.

Tabel 5. Hasil Uji Homogenitas

\section{Levene's Test of Equality of Error Variances ${ }^{\mathrm{s}}$}

\begin{tabular}{|c|c|c|c|}
\hline$F$ & $\mathrm{df1}$ & $\mathrm{d} f 2$ & Siq. \\
\hline 1.799 & 3 & 92 & .153 \\
\hline
\end{tabular}

Tests the null hypothesis that the error variance of the dependent variable is equal across groups.

a. Design: Intercept + Moral + SPI + Moral * SPI 
Untuk pengujian hipotesis dilakukan melalui analisis ANOVA test of betweensubjects yang ditunjukkan pada Tabel 6.

Tabel 6. Hasil Uji Hipotesis

Tests of Between-Subjects Effects

\begin{tabular}{|c|c|c|c|c|c|}
\hline Source & $\begin{array}{c}\text { Type III Sum } \\
\text { of Squares }\end{array}$ & df & Mean Square & $\mathrm{F}$ & Siq. \\
\hline Corrected Model & $226.261^{=}$ & 3 & 75.420 & 9.614 & .000 \\
\hline Intercept & 2959.095 & 1 & 2959.095 & 377.201 & .000 \\
\hline Moral & 118.829 & 1 & 118.829 & 15.147 & .000 \\
\hline SPI & 36.126 & 1 & 36.126 & 4.605 & .035 \\
\hline Moral * SPI & 83.924 & 1 & 83.924 & 10.698 & .002 \\
\hline Error & 721.729 & 92 & 7.845 & & \\
\hline Total & 3841.000 & 96 & & & \\
\hline Corrected Total & 947.990 & 95 & & & \\
\hline
\end{tabular}

a. R Squared $=.239$ (Adjusted R Squared $=.214$ )

Hasil analisis menunjukkan bahwa nilai sig. untuk efek moralitas individuyaitu $0,000<0,05$. Oleh karena itu $\mathrm{H}_{1}$ diterima dan disimpulkan terdapat perbedaan kecenderungan kecurangan akuntansi antara individu yang memiliki level moralitas tinggi dan level moralitas rendah. Sedangkan nilai sig. untuk efek pengendalian internal yaitu sebesar $0,035<0,05$ menunjukkan bahwa $\mathrm{H}_{2}$ juga diterima. Sehingga dapat disimpulkan bahwa terdapat perbedaan kecenderungan kecurangan akuntansi antara individu dalam kondisi terdapat elemen pengendalian internal dan tidak terdapat elemen pengendalian internal.

Nilai mean pada Tabel 2 menunjukkan bahwa grup tiga (3) dan grup empat (4) dengan kondisi moral rendah memiliki nilai mean yang lebih tinggi dibandingkan grup satu (1) dan grup dua (2). Hal ini berarti partisipan yang memiliki moral rendah cenderung untuk melakukan kecurangan akuntansi dibandingkan dengan partisipan yang memiliki moral tinggi. Hasil ini sesuai dengan tahapan perkembangan moral Kohlberg dimana individu yang memiliki tahapan moralitas tinggi akan semakin menghindarkan diri dari kecurangan akuntansi karena memiliki sikap etis dan mengutamakan kepentingan universal lebih tinggi daripada kepentingan pribadinya(Welton, 1994; Wilopo, 2006; Liyanarachi, 2009; Puspasari, 2012; Dewi, 2014).

Dukungan terhadap hipotesis $\mathrm{H}_{3}$ juga ditunjukkan oleh nilai sig. sebesar $0,02<0,05$ sehingga dapat disimpulkan bahwa terdapat interaksi yang signifikan antara moralitas individu dengan pengendalian internal. Kondisi ada atau tidak ada pengendalian internal dalam sebuah organisasi akan membuat individu dengan level moral tertentu akan cenderung melakukan kecurangan akuntansi. Perubahan level kondisi elemen pengendalian internal (ada dan tidak ada elemen pengendalian internal akan mengakibatkan dampak perubahan pada individu dengan level moral tertentu (tinggi atau rendah) untuk melakukan kecurangan akuntansi. Hasil tersebut ditunjukkan dengan melihat perbandingan mean antara grup empat (4) dengan grup dua (2) dan grup tiga (3). Pada kondisi tidak ada pengendalian internal maka individu yang memiliki moralitas rendah akan cenderung melakukan kecurangan akuntansi. Namun pada kondisi ada pengendalian internal individu yang memiliki moral rendah (grup 3) memiliki nilai mean 
yang lebih kecil dibandingkan grup empat (4). Hal ini berarti pengendalian internal menjadi alat yang cukup efektif untuk mencegah terjadinya kecurangan akuntansi, karena individu yang memiliki moral rendah lebih berorientasi pada sanksi hukum dan peraturan (Moroney dan McDevitt, 2008; Wilopo, 2006). Temuan ini menguatkan rekomendasi bahwa kesesuaian sistem pengendalian internal merupakan faktor yang efektif dalam mengendalikan perilaku tidak etis dan kecenderungan terjadinya kecurangan akuntansi (Thoyibatun, 2009; Prawira dkk, 2014).

Untuk pengujian hipotesis keempat dilakukan dengan analisis uji beda Mann Whitney disebabkan oleh data yang tidak normal, ditunjukkan pada tabel 7 terhadap individu yang memiliki jenis kelamin yang berbeda pada grup empat (4).

Tabel 7. Hasil Uji Beda

\begin{tabular}{|c|c|c|c|c|}
\hline \multicolumn{5}{|c|}{ Ranks } \\
\hline & Gender & $N$ & Mean Rank & Sum of Ranks \\
\hline \multirow[t]{3}{*}{ Fraud } & Perempuan & 12 & 8.42 & 101.00 \\
\hline & Laki-laki & 10 & 15.20 & 152.00 \\
\hline & Total & 22 & & \\
\hline
\end{tabular}

Test Statistics ${ }^{b}$

\begin{tabular}{|l|r|}
\hline & \multicolumn{1}{|c|}{ Fraud } \\
\hline Mann-Whitney U & 23.000 \\
Wilcoxon W & 101.000 \\
$Z$ & -2.670 \\
Asymp. Sig. (2-tailed) & .008 \\
Exact Sig. [2*(1-tailed & $.014^{=}$ \\
\hline
\end{tabular}

a. Not corrected for ties.

b. Grouping Variable: Gender

Hasil analisis menunjukkan nilai sig. 0,08 $<0,05$ yang berarti $\mathrm{H}_{4}$ diterima dan terdapat perbedaan kecenderungan kecurangan akuntansi antara individu berjenis kelamin laki-laki dengan berjenis kelamin perempuan pada level moralitas rendah dan tidak terdapat pengendalian internal. Hal ini menunjukkan adanya pengaruh gender dalam hal pengambilan keputusan akuntansi, dimana wanita cenderung memiliki sikap konservatisme yang tinggi, berhati-hati serta lebih teliti.

\section{PENUTUP}

Penelitian menggunakan teknik eksperimen lapangan masing sangat jarang dilakukan terutama dalam topik kecurangan akuntansi di lingkungan Perguruan Tinggi. Penelitian sebelumnya hanya menggunakan partisipan dari pihak mahasiswa terkait pendidikan etika. Oleh karena itu, penelitian ini dilakukan untuk mengetahui pengaruh moralitas dan pengendalian internal terhadap kecenderungan kecurangan akuntansi. Hasil penelitian menunjukkan adanya perbedaan kecenderungan terjadinya kecurangan akuntansi yang disebabkan oleh level moralitas, pengendalian internal dan gender. Penelitian ini berhasil membuktikan pentingnya pendidikan etika dan karakter di lingkungan Perguruan Tinggi 
serta adanya prosedur pengendalian internal yang baik akan dapat mencegah terjadinya kecurangan akuntansi.

Namun, penelitian ini juga tak lepas dari banyak kendala dan keterbatasan terkait waktu pelaksanaan eksperimen. Penelitian selanjutnya diharapkan dapat menyempurnakan skenario penelitian dan memperluas sampel pada Universitas Negeri maupun swasta lainnya untuk memperoleh hasil generalisasi yang lebih baik.

\section{DAFTAR RUJUKAN}

American Institute of Certified Public Accountant and Association of Certified Fraud Examiners (ACFE). (2009) Managing The Business Risk of Fraud: A Practical Guide. Association of Certified Fraud Examiners.

Albrecht, S. W. and C. Albrecht. (2004) Fraud Examination and Prevention. Australia: Thomson, South-Western.

Arens, A dan Loebbecke, (2003) Auditing:Suatu Pendekatan Terpadu, Edisi Indonesia, Salemba Empat Jakarta.

Bastian, Indra. (2006) Akuntansi Sektor Publik: Suatu Pengantar. Erlangga.

Bernardi, R. and S. Guptill. (2008) Social Desirability Response Bias, Gender and Factors Influencing Organizational Commitment: An International Study. Journal of Business Ethics.

Bologna, J. (1993) Handbook of Corporate Fraud. Boston; Butterworth-Heinemann.

Chung, J., Monroe, G. S. (2001) A Research Note on the Effect of Gender and Task Complexity on an Audit Judgement. Behavioral Research in Accounting. Vol.13

Coram, P., C. Ferguson, and Moroney, R. (2008) Internal Audit, Alternative Internal Audit Sructures and The Level of Misapropriation of Assets Fraud. Accounting and Finance vol. 48

Cressey, D. (1953) Other People's Money: a Study in the Social Psychology of Embezzlement. Glencoe, IL: Free Press.

Dewi, G.A.K. Rencana Sari. (2014) Pengaruh Moralitas Individu dan Pengendalian Internal Pada Kecurangan Akuntansi (Studi Eksperimen Pada Pemda Provinsi Bali). Tesis. Program Pasca Sarjana Unud Denpasar.

Dewi YR, Rozmita dan Nelly Nur Apandi. (2012) Gejala Fraud dan Peran Auditor Internal Dalam Pendeteksian Fraud di Lingkungan Perguruan Tinggi (Studi Kualitatif). Simposium Nasional Akuntansi XV. Banjarmasin.

Dorminey, J., A. S. Fleming., M.J. Kranacher, and R. A. Riley. (2011) "Beyond The Fraud Triangle. Enhancing Deterrence of Economic Crimes". CPA Journal.

Drew, J. M dan Drew, M.E. (2010) "Establishing Additionality: Fraud Vulnerabilities in the Clean Development Mechanism”. Accounting Research Journal 23(3), 243- 253

Hernandez, J. R. and T. Groot. (2007) Corporate Fraud: Preventive Controls Which Lower Corporate Fraud. Amsterdam Research Centre in Accounting.

Hogan, C. E., Z. Rezaee., R. A. Riley., dan U. K. Velury. (2008) Financial Statement Fraud: Insights From The Academic Literature. Auditing: A Journal of Practice and Theory vol 27.

Kohlberg, L. (1969) Stage and Sequence: The Cognitive-Development Approach Moral Action to Socialization. In D. A. Goslin (Ed). Handbook of socialization theory and research (pp.347-480). Chicago: RandMcNally 
Kusumastuti, S., Supatmi, dan Sastra, P. (2007) "Pengaruh Board Diversity terhadap Nilai Perusahaan dalam Perspektif Corporate Governance". Jurnal Akuntansi dan Keuangan. 9 (2), 88-98.

Liyanarachi, G. (2009) The Impact of Moral Reasoning and Retaliation on WhistleBlowing: New-Zealand Evidence. Journal of Business Ethics 89.

Moroney, J. J. and R. E. McDevitt. (2008) The Effects of Moral Reasoning on Financial Reporting Decisions in a Post Sarbanes-Oxley Environment. Behavioral Research of Accounting

Mulyadi. (2009) Auditing Edisi 6 Buku 1, Penerbit Salemba Empat, Jakarta

Noviyanti, Suzy. (2008) Skeptisisme Profesional Auditor dalam Mendeteksi Kecurangan untuk Mencapai Prosedur Audit yang Efektif. Disertasi Tidak Dipublikasikan. Program Doktor, Universitas Diponegoro.

Prawira, I Made Darma, Nyoman Trisna Herawati dan Nyoman Ari Surya Darmawan. (2014) "Pengaruh Moralitas Individu, Asimetri Informasi dan Efektivitas Pengendalian Internal Terhadap Kecenderungan Kecurangan (Fraud) Akuntansi”. $e$ Journal Universitas Pendidikan Ganesha, 2 (1).

Puspasari, N. (2012) "Pengaruh Moralitas Individu dan Pengendalian Internal terhadap Kecenderungan Kecurangan Akuntansi: Studi Eksperimen pada Konteks Pemerintahan Daerah". Tesis. Yogyakarta: Program Pasca Sarjana UGM

Ramamoorti, S. (2008) The Psychology and Sociology of Fraud: Integrating the Behavioral Sciences Component Into Fraud and Forensic Acounting Curricula. Issues in Accounting Education vol. 23.

Rest, J. R. (2000) “A Neo-Kohlbergian Approach To Morality Research”. Journal of Moral education vol 29.

Sekaran, U. (2006) Research Methods For Business, Edisi 4, Buku 2, Jakarta: Salemba Empat

Singleton \&Singleton. (2010) Fraud Auditing and Forensic Accounting. Fourth Edition Wiley Corporate F\&A

Thoyibatun, Siti. (2009) "Faktor-Faktor yang Berpengaruh Terhadap Perilaku Tidak Etis Dan Kecenderungan Kecurangan Akuntansi Serta Akibatnya Terhadap Kinerja Organisasi”. Ekuitas:Jurnal Ekonomi dan Keuangan, 16 (2), 245-260

Wells, J. T. (2007) Corporate Fraud Handbook: Prevention and Detection: Second Edition.John Wiley and Sons Inc.

Welton, R. E., J. R Davis dan M. LaGroune. (1994) "Promoting The Moral Development Of Accounting Graduate Students". Accounting Education. International Journal 3.

Wilopo. (2006) "Analisis Faktor-Faktor yang Berpengaruh TerhadapKecenderungan Kecurangan Akuntansi: Studi pada Perusahaan Publik dan Badan Usaha Milik Negara (BUMN) di Indonesia”. Jurnal Riset Akuntansi Indonesia vol.9.

Yu, BTW dan Ming, TW. (2008) "Effects of Control Mechanisms on Positive Organizational Change”. Journal of Organizational Change Management, 21(3), $385-404$

www.infokorupsi.com diakses tanggal 20 Maret 2015 